\title{
Unfair practices and illicit conduct in food supply chains in Slovenia
}

\author{
Jože PODGORŠEK ${ }^{1}$
}

Received January 19, 2017; accepted May 05, 2017.

Delo je prispelo 19. januarja 2017, sprejeto 05. maja 2017.

\begin{abstract}
The food supply chain in Slovenia is highly developed, but it involves unequally developed stakeholders with different bargaining power. Upon reviewing all stakeholders through participatory research, it is made clear that in the whole food supply chain, retail chains generally have the greatest and primary producers the smallest bargaining power. For this reason, in the process of regulating mutual relations in contractual commitments and mutual operations, unfair practices and illicit conduct often emerge, through which the parties with significant market power impose additional discounts, rebates and other contributions on the parties with smaller market power in order to improve their own financial management. Unfair practices and illicit conduct lead to the weakening of the entire food supply chain, so it is important to recognise such tendencies in the food chain. In this article, the autor would like to draw attention to the illicit conduct and unfair practices in Slovenia which are used by retail chains in their interpersonal relationships and their dealings with suppliers.
\end{abstract}

Key words: unfair practices; illicit conduct; food supply chain; significant market power; imposition of conditions

\section{IZVLEČEK \\ NEPOŠTENE PRAKSE IN NEDOVOLJENA RAVNANJA V VERIGI PRESKRBE S HRANO V SLOVENIJI}

Veriga preskrbe s hrano v Sloveniji je izredno razvita, vendar $\mathrm{V}$ njej sodelujejo različno razviti deležniki $\mathrm{Z}$ različno pogajalsko močjo. Ob pregledu vseh deležnikov preko participativnega raziskovanja se izlušči, da imajo največjo pogajalsko moč $\mathrm{v}$ celotni verigi preskrbe $\mathrm{s}$ hrano trgovske verige in praviloma najmanjšo primarni pridelovalci. Zaradi tega so pri urejanju medsebojnih odnosov pogosto $\mathrm{v}$ pogodbenih zavezah in medsebojnem poslovanju prisotne nepoštene prakse in nedovoljena ravnanja, $\mathrm{s}$ katerimi stranke $\mathrm{z}$ znatno tržno močjo vsiljujejo dodatne popuste, rabate in druge prispevke strankam $\mathrm{z}$ manjšo tržno močjo $\mathrm{z}$ namenom izboljševanja svojega finančnega poslovanja. Zaradi nepoštenih praks in nedovoljenih ravnanj prihaja do slabitve celotne verige preskrbe $\mathrm{s}$ hrano, zato je pomembno, da jih $\mathrm{v}$ verigi preskrbe $\mathrm{s}$ hrano prepoznamo. $\mathrm{V}$ tem prispevku želim opozoriti na nepoštene prakse in nedovoljena ravnanja, ki so jih trgovske verige v Sloveniji vključile v medsebojne odnose pri poslovanju z dobavitelji.

Ključne besede: nepoštene prakse; nedovoljena ravnanja; veriga preskrbe s hrano; znatna tržna moč; vsiljevanje pogojev

\section{INTRODUCTION}

The food supply chain is a major employer in Europe and the Slovenian area. On the basis of the data in the report presented by the European Parliament (Jackiewicz, 2015), more than 47 million people in the EU are employed by the food sector. Production, processing, logistics and food sales in Slovenia employ all together about 87.000 people (ReSURSKŽ, 2011), and additional new jobs will be opened up, which is due to the increasing self-sufficiency in Slovenia. Because of the quality jobs in the operating agri-food chain, the needs of the state for various social transfers are being consequently reduced. Increased production and food processing have lead to the growing consumption of raw materials for agricultural production and thus the revenues to the state budget have increased. A wellfunctioning agri-food chain promotes economic growth equally well and increases the purchasing power of rural areas. Increasing demand for food of Slovenian origin generates other aspects of preserving the Slovenian countryside as well, enabling the development of other

1 Food supply chain relationships ombudsman, The Ministry of agriculture, forestry and food, Dunajska 22, SI-1000 Ljubljana, Slovenia, e-mail address: joze.podgorsek@gov.si

Translator: dr. Alenka Divjak, Visoka šola za upravljanje podeželja Grm Novo mesto, Sevno 13, 8000 Novo mesto, e-mail address: alenka.divjak@guest.arnes.si 
industries, such as tourism, sports, recreation, and more. In view of all these aspects, it is extremely important that the food supply chain is solid and sustainable. The strength of the food supply chain is undoubtedly influenced by the relations between its various partners as well. Because of the uneven market position of various partners involved in the food supply chain, smaller food producers in particular are affected by unfair practices which in the long run weaken the partners on whom these practices are imposed. In general, unfair practices can be defined as the practices that significantly deviate from sound business conduct, being contrary to good faith and honest conduct, and which are unilaterally imposed on the others by one partner or a group of partners. Illicit conduct can be classified as non-compliance with payment deadlines and the imposition of conditions (additional payments, discounts, promotions, unfair delivery conditions, counter trade by non-competitive conditions, transfer of business risk to trade suppliers, etc.) (ZKme1B, 2014). Such improper practices evolve there where is no balance in the financial and consequently in the bargaining power of business partners, impairing in this way the entire EU economy, because as a result of such actions, businesses (especially small and medium ones) are losing the ability to invest and foster innovations and they consequently do not decide to expand their business in the single market. Attention should be paid to the factor of fear, when the weaker partners decide not to initiate legal action in spite of the exisisting possibility to do so, and irrespective of the damage, they simply accept unfair practices because they are afraid that a stronger partner may otherwise terminate a business relationship.

Although the imbalances in bargaining power are a completely legitimate component of the functioning of the market, the abuse of a stronger position can distort the relationship between the companies, which often leads to unfair trading practices. This question concerning the transactions between enterprises has been increasingly coming to the force in recent years, and although it is difficult to evaluate all its dimensions, there are concrete statistics and market evidence revealing that unfair practices in the food chain are fairly widespread, especially in certain parts of the agrifood chain. It is being recognized by many Member States that such practices can cause a lot of damage, so they are taking action against them, while the other members are planning to do the same. The rules in this area as well as the extent of this problem vary greatly among the Member States. At the same time, market participants are trying to confront the problem by developing principles of good practice in vertical relationships and by designing self-regulatory frameworks for the implementation of these principles (Evropska komisija, 2014; Kocsis and Nedeczky, 2013). However, as unfair practices are widespread and they are becoming more and more problematic, the question is being raised in this article: to what extent can selfregulatory mechanisms actually help to restore market equilibrium? Voluntary mechanisms that encourage companies to refrain from unfair practices should supposedly mitigate this problem to some degree, but they certainly cannot solve it (Jackiewicz, 2015). For the effective prevention of unfair practices and illicit conduct, the identification of such unfair practices is of the utmost importance. For that reason, in the continuation of this article, its author will present the identified suspicions of unfair practices and illicit conduct that occur in the Slovenian food supply chain, with the emphasis on the retail chains recognized as the parties with significant market power.

\section{MATERIAL AND METHODS}

In Slovenia, the food supply chain is extremely dynamic and, due to the proverbial incoherence of individual actors, it is fairly different from similar chains in the neighbouring countries. So in Slovenia, there are the following types of food supply chains (Podgoršek, 2016):

1. agricultural holding — retail chain (typical for the sector of fresh vegetables, potatoes),

2. agricultural holding - cooperative - retail chain (some examples in the sector of vegetables and fruit),

3. agricultural holding - food processing company - retail chain (typical for the sector of meat and grain),
4. agricultural holding - cooperative - food processing company - retail chain (typical for the milk sector),

5. food processing company - retail chain (typically for the sector of drinks).

Due to the highly fragmented structure of different stakeholders, a decision has been taken by the author to analyze the relationships in the food supply chain at the point where all retail chains and their suppliers join in. To establish the suspicion of unfair practices and illicit conduct, the method of participatory active research has been chosen. This is one of the research tools connecting participants in this research with the purpose of finding a common definition and a solution to the problem. For this reason, one of the important 
objectives of this research is also its active contribution to the solution to certain social problems. It is oriented to promoting skills, community development, social justice, wider accessibility and the participation of different stakeholders (Podmenik and Bembič, 2015).

In accordance with the selected method, the author personally interviewed a variety of Slovenian suppliers of retail chains in Slovenia, maintaining in this way the anonymity of the participants in the research, as all the time throughout the present research, it was possible to recognize the participants' fear that sanctions might be imposed on them by retail chains in the case of their identity being revealed. For this reason, the obtained information was combined and merged in such a form that a clear source of information can no longer be identified. The research has been conducted in all the main groups of suppliers who have been divided into the following five groups:

- meat and meat products,

- milk and dairy products,

- $\quad$ fruits and vegetables (fresh and processed),

- the manufacture of grain mill and bakerymanufacture,

- the manufacture of other food products.

The research was conducted among different types of suppliers, such as farms, agricultural cooperatives and agro-processing companies.

\section{RESULTS AND DISCUSSION}

In the Slovenian area, unfair practices and illicit conduct have been actively dealt with for many years due to the increasing concern of both stakeholders and agricultural policy who recognized the seriousness of the existing anomalies. The first serious attempt to restrict the development of unfair practices was the signing of the Code of good business practices among stakeholders in the agri-food chain at the Agra Fair 2011. The Code signatories (the Slovenian Chamber of Commerce, the Slovenian Chamber of Commerce and Industry, The Chamber of Agriculture and Forestry, the Slovenian Chamber of Craft and Small Business and the Cooperative Association of Slovenia) then agreed to develop positive relationships and promote the joint development of the food supply chain. The Code also envisaged the introduction of the net purchase prices in retail chains, planning to implement the agreement by early 2013 (Kodeks, 2011). Due to non-compliance with the commitments contained in the Code, the Law on amending the Law on agriculture $(\mathrm{Zkme}-1 \mathrm{~B}, 2014)$ was accepted. The amendment to the Law on agriculture set a 45-day maximum payment period for perishable foodstuffs and 90 days for other foods. It also identified illicit conduct and provided a legal basis for the appointment and functioning of a food supply chain relationships ombudsman. The first ombudsman was appointed on 3 January, 2015, for a period of five years. The ombudsman's task is to monitor the behaviour of stakeholders in the food supply chain, to publish examples of good business practices and to notify the Public Agency for the Competition Protection of any prohibited practices, whereby the Public Agency has to protect personal information and business secrets of the parties.

On the basis of the analysis of the results obtained by the method of participatory active research, the author of the article divided the allegations of unfair practices and illicit conduct, made by individual participants, into five groups, without making any direct references to the participants in order to prevent the revelation of the trade secrets of individual stakeholders.

biomass of wheat. Results revealed that germination percentage was neither affected by different plant parts nor by extract concentrations. Interaction between plant parts and concentrations were also non-significant. Germination (\%) was maximum (91.8) in control conditions. Slighter decrease in germination was observed in petri-dishes treated with different extract concentrations of different plant parts; however, the differences among means of concentrations and plant parts for germination percentage were insignificant and they ranged between $89.7-90.9 \%$ which did not differ significantly from $91.8 \%$ in control (Table 1 ).

\subsection{Retail chain 1:}

In this chain, the following allegations of unfair practices have been found:

- the imposition of additional discounts and rebates amounting to over $20 \%$ according to the value of delivered food products.

\subsection{Retail chain 2:}

In this chain, the following allegations of unfair practices have been found:

- the imposition of additional discounts in the form of charging superrabates (different rates depending on the supplier), additional payments for marketing up to $2 \%$ of current output,

- the requirement for agreed action prices of items for products in the weekly specials for the period from 16 days before the special (also for food products with a shorter shelf life) and 
up to 7 days after the completion of the special, which means that they require the action price for the article in a weekly special for the period of 1 month,

- the return of already delivered and absorbed goods - the transfer of risk to suppliers,

- the signing of a contract with the company for transferring money, recommended by the retail chain (the company for transferring money is through the founders associated with the retail chain), and billing the service of transfer up to $1 \%$ in relation to payments made,

- the dictation of action prices that are lower than the prices in comparable neighboring countries, with the possibility of immediate loss of business in the case of the supplier's disagreement with the proposed price,

- the application of fines and penalties on the delayed or failed delivery of a certain item, in no proportion to the damage caused,

- the increase of various discounts in the case of the exclusion of the supplier of this trading system and his re-integration into the network of suppliers.

\subsection{Retail chain 3:}

In this chain, the following allegations of unfair practices have been found:

- the imposition of individual contracts on individual suppliers to pay up to $5 \%$ of the total turnover of the previous year,

- contractual restriction of the right to charge default interest on the late payment of invoices and transfer of commercial risk to the supplier in the case of sales actions,

- bound trade at non-competitive prices in the case of franchises,

- opaque rejection of goods due to possible defects in food products or crops,
- exclusion of one's own-brand products which are in other retail chains marketed by the same suppliers under the commercial brand of a competitive retail chain.

\subsection{Retail chain 4:}

In this chain, the following allegations of unfair practices have been found:

- the transfer of the business risk to the supplier in the case of action sales,

- payment defaults and late payments for nutritional products, the lack of consent to the sale of receivables overdue to the purchasers of receivables,

- contractual restriction of the right to charge default interest on the untimely paid accounts,

- late payments (in some cases more than 90 days after currency),

- bound trade at non-competitive prices in the case of franchises.

\subsection{Retail chain 5:}

In this chain, the following allegations of unfair practices have been found:

- the coercion of small suppliers into the exclusive sale of their products only through a particular retail chain.

The list of suspected unfair practices and illicit conduct is unfortunately being constantly updated. During the action, taken by the food supply chain relationships ombudsman in one of the retail chains, compulsory payments for early payment of invoices (paid within 20 days instead of envisaged 45 days) were replaced with compulsory promotional rebate, which is probably due to the alertness to a usurious interest rate in the case of pre-payment of bills. It should be noted that suppliers continue to pay special promotions according to the price list of the retail chain.

\section{CONCLUSIONS}

Unfair trade practices are recognized throughout Europe and they are quite common. In the pan-European survey, conducted among suppliers in the food chain, $96 \%$ of suppliers stated that they met with at least one form of unfair trade practices (Evropska komisija, 2014). However, there are considerable differences among individual EU countries. Thus, some national studies have shown different shares of the existence of unfair trade practices. In Spain, the national survey has found that $56 \%$ of suppliers experienced retroactive changes in the contract terms. In Italy, a survey has shown that $57 \%$ of producers often or always accept unilateral retroactive changes, from fear of commercial retaliation in the case of the rejection of changes. The overall impact of unfair trade practices is difficult to assess and quantify in quantitative terms, however, as a result of these practices, those parties are directly and negatively affected. Because of the unfair trade practices, the income of suppliers is undoubtedly reduced.

The unfair practices and illicit conduct in the food supply chains are dealt with by various European countries in different ways. The Czech Republic applies the Act on abuse of a dominant market position in the market of agricultural and food products (Official 
Journal of the EU, 2013). The law in question among others prohibits the sale of a product at a price lower than its purchase price and only the net price is to be considered, without any additional discounts and rebates. In Italy, they use the Regulation on economic relations in the sale of food and agricultural products (Oggetto, 2016), which specifies mandatory and prohibited elements in contracts. The control over the implementation of the regulation is kept by the Authority for the competition and the market, which can also rely in special cases on the operational support of the Financial Guard (Guardia di Finanza). In neighboring Hungary, it is the Trade act (RS Government, 2013) which governs the relations in the food supply chain and which defines the abuses committed by traders with the dominant market power. The law should protect the suppliers and it is based on the protection of free trade and entrepreneurship. From 2012 onwards, the law no longer applies to food products. Therefore, the chain of food products and the prevention of unfair practices are today regulated by the Trade act and the Law on unfair distribution practices.
The supervision of the implementation of the legislation is in the domain of the State Office for the safety of the food chain.

To sum up, the food supply chain in different EU countries is regulated in different ways. All the countries, however, share a common interest in regulating the relations existing in this chain and endeavour to prevent the exploitation of negotiating superiority achieved by individual stakeholders. Therefore, this problem, in addition to the food supply chain relationships ombudsman, is dealt with by the Public Agency of the Republic of Slovenia for Protection of competition, which was notified of the suspicions of unfair practices and illicit conduct by the ombudsman in January 2016. Nevertheless, it is likely that in Slovenia it will also be necessary to adopt a legislative framework through which the relations in the food supply chain will be regulated and unfair practices prevented, especially the pressure exerted on weaker negotiators by the parties with significant market power.

\section{REFERENCES}

Evropska komisija. (2014). Sporočilo komisije evropskemu parlamentu, svetu, evropskemu ekonomsko socialnemu odboru in odboru regij, Evropska komisija, Strasbourg, COM(2014) 472 final, 15.7.2014.

Jackiewicz, D. B. (2015). Osnutek poročila o nepoštenih trgovinskih praksah $\mathrm{v}$ verigi preskrbe $\mathrm{s}$ hrano, Evropski parlament, Odbor za notranji trg in varstvo potrošnikov, Bruselj, 9 str.

Kodeks. (2011). Kodeks dobrih poslovnih praks med deležniki $\mathrm{v}$ agroživilski verigi. Objavljeno na spletni strani: https://www.gzs.si/pripone/KODEKS\%20\%2023\%208\%202011.pdf. 1.12.2016.

Kocsis, M., Nedeczky, A. (2013). Your RFI concerning the assesment of harmful effects in the food supply chain, Budapest, 4 str.

Oggetto. (2016). Oggetto: DL 24.12012 n. 1, art. 62 recante "Disciplina delle relazioni commerciali in materia di cessione di prodotti agricoli $e$ agroalimentari«.
Podgoršek, J. (2016). Letno poročilo varuha odnosov v verigi preskrbe s hrano, Ljubljana, 22 str.

Podmenik, D., Bembič, M. (2015). Novi raziskovalni pristopi $\mathrm{v}$ družbeni geografiji: participativno akcijsko raziskovanje. Geografski vestnik, 87,2, 105 - 113. doi:10.3986/GV87207

ReSURSKŽ. (2011). Resolucija o strateških usmeritvah razvoja slovenskega kmetijstva in živilstva do leta 2020 - »Zagotovimo.si hrano za jutri« (ReSURSKŽ), Uradni list RS, št. 25/11, 4.4.2011.

Uradni list EU. (2013). Mnenje Evropsko ekonomskosocialnega odbora o zeleni knjigi o nepoštenih trgovinskih praksah $\mathrm{v}$ oskrbni verigi $\mathrm{z}$ živili in neživili med podjetji v Evropi. Uradni list Evropske unije. COM(2013) 37 final, 7 str.

Vlada RS. (2013). Predlog Zakona o spremembah in dopolnitvah Zakona o kmetijstvu. Objavljeno na spletni strani: http://imss.dzrs.si/imis/316beffb1414f838cf7e.pdf. 1.12.2016

ZKme-1B. (2016). Zakon o spremembah in dopolnitvah Zakona o kmetijstvu, Uradni list RS, št. 26/14, 14.4.2014. 